\title{
Optimized Regulated Deficit Irrigation Management for Watermelon Cultivation in a Semiarid Region
}

\author{
Kelly Nascimento Leite \\ CMULTI.- Cruzeiro do Sul, Brazil \\ University Federal of Acre \\ Daniel Fonseca de Carvalho \\ Technological Institute / Engineering Department, Brazil \\ University Federal Rural of Rio de Janeiro \\ Jose Maria Tarjuelo Martin- Benito \\ C.U. Ingenieria Agroforestal / Director del CREA, Spain \\ University of Castilla La Mancha \\ Geocleber Gomes de Sousa \\ Rural Development Institute, Brazil \\ Afro-Brazilian University of International Integration \\ Alfonso Dominguez Padilla \\ CREA - UCLM, Spain \\ University of Castilla La Mancha
}

Received: December 17, 2020

Accepted: February 7, $2021 \quad$ Published: March 8, 2021

doi:10.5296/jas.v9i2.18088

URL: https://doi.org/10.5296/jas.v9i2.18088

\section{Abstract}

The present study aimed to validate the MOPECO crop simulation model and to determine a 
viable irrigation management for watermelon in the semiarid region of Northeast Brazil, using methodologies of optimized regulated deficit irrigation (ORDI) and constant deficit irrigation (CDI). The experiment was carried out during October to December 2013 and the second one from July to August 2014 in plots of land of producers in the Baixo Acaraú Irrigated Perimeter - Ceará, Brazil. Treatments were characterized by ORDI management (70, $80,90 \% \mathrm{ET}_{\mathrm{a}} / \mathrm{ET}_{\mathrm{m}}$ ratio) and CDI management along the entire cycle (70, 80 and $\left.90 \% \mathrm{ET}_{\mathrm{m}}\right)$ and control treatment, irrigated with $100 \%$ of the water requirement of the crop $\left(\mathrm{ET}_{\mathrm{m}}\right)$. In terms of saving of water resources, the results showed that management with regulated deficit irrigation leads to favorable and economically viable results for the farmer, of water saving, especially in a situation of severe water scarcity, irrigation management with regulated water deficit (ORDI) can provide favorable and economically viable results for the farmer. The highest value of WUE $\left(41.8 \mathrm{~kg} \mathrm{~m}^{-3}\right)$ was obtained with the treatment of lowest water volume applied $(352.1 \mathrm{~L})$ in the second experiment, decreasing with the increase in the water volume used. The ORDI methodology represents a better water use efficiency for all treatments of deficit applied compared to CDI treatments. The difference of ORDI and CDI methodology provided an increase of up to $200 \%$ in the gross margin obtained with the exploration of the watermelon culture which represents a range of $\mathrm{R} \$ 986.00$ in profit in a situation of water scarcity, as in the case of the studied region, the strategy with water supply of $70 \%$ of $\mathrm{ET}_{\mathrm{a}} / \mathrm{ET}_{\mathrm{m}}$ ratio regulated by phenological stage was recommended in order to obtain highest water use efficiency.

Keywords: irrigated fruit production, simulation models, MOPECO

\section{Introduction}

Watermelon (Citrullus lanatus) is one of the main fruits produced in the world and China stands out for being the largest producing country (74.843.000 TonM and having the highest yield (40.4 Ton ha-1). Brazil is the fourth largest producer in the world, despite the low yield (23.0 Ton $\mathrm{ha}^{-1}$ ) that occurs due to the lack of adequate managements of soil fertilization (Lucena et al., 2013) and irrigation (Andrade Júnior et al., 2010). Considered the fourth most important vegetable in the country, with $27 \%$ of the national production concentrated in the Northeast region (Sousa et al., 2016), watermelon is one of the most cultivated short-cycle crops in irrigated perimeters administered by the National Department of Works Against Drought - DNOCS (Saraiva et al., 2013).

As the population and economic progress increase, the demand for quality water increases proportionally (Davies; Simonovic, 2011), especially in regions with arid and semi-arid climates. The increase or consumption of two predominant uses other than water and climate change (FAO, 2003), makes the sustainability of this resource uncertain. One of the main sources of income for the population of the semi-arid region of Northeast Brazil concerns family farming, in which the cultivation of irrigated watermelon stands out, as it offers a high economic return on low water demand (Wang et al., 2004), due to the low incidence of rain and intense evaporation in the region, affecting its production and increasing production costs.

Given the need to optimize water use in agricultural production, the development of tools and 
protocols aimed at maximizing yield with lower water consumption has become frequent (Steduto et al., 2012), generating agrometeorological models for crop yield estimation, such as AquaCrop, CropSyst and WOFOST. The MOPECO (Economic optimization model for irrigation water management) model has been employed, allowing in a relatively simple way decisions to be made in regard to the irrigation management to be adopted in an agricultural property (Leite et al., 2015b).

Using crop simulation models allows producers and researchers to better plan activities related to the agricultural calendar (including irrigation) of a given crop, in order to increase the profits of the agricultural unit (Steduto et al., 2012, Raes, 2009; Garcia-Vila, 2009).

The current situation of agricultural production presents, in many aspects, high levels of uncertainty when analyzed or a production system in a general context. (Geerts; Raes, 2009). The MOPECO model was designed to optimize the gross income of irrigated agricultural properties, especially in areas with water scarcity or cultivation with high management costs (GM). This model developed ORDI for limited volumes of irrigation water, which modifies the ETa / ETm objective of the different Ky stages in several consecutive optimizations, according to the progression of the real climatic conditions, the amount of irrigation water applied at the end of each stage, and the volume available for the following ones. In order to maximize yield, the methodology determines the deficit in terms of ETa / ETm to be applied to the crop at each Ky stage and estimates the amount of irrigation water required to reach that level of deficit this model was calibrated in several regions that use irrigation in the world: Castilla - La Mancha (CLM) and Basque Country (Spain); In the Bekaa Valley (Lebanon); San Luis, (Argentina;) Ceará and Rio de Janeiro (Brazil) and for crops, melon, onion, garlic, carrot and potato.(Leite et al., 2015, Domínguez et al., 2013)(Domínguez et al., 2012; Leite et al., 2015)

In view of the above, the present study aimed to validate the MOPECO model and to determine a viable irrigation management for watermelon cultivation in the semiarid region of Northeast Brazil using the methodologies of optimized regulated deficit irrigation (ORDI) and constant deficit irrigation (CDI).

\section{Material and Methods}

\subsection{Site Description}

The study was carried out in plots of land of producers in the Baixo Acaraú Irrigated Perimeter, located in the Northern region of Ceará - Brazil, close to the estuary of the Acaraú River, encompassing part of the municipalities of Acaraú, Bela Cruz and Marco. The Irrigated Perimeter is inserted in the topographic divider of two hydrographic basins, in the lower part of the Acaraú River Basin and in the Coastal Basin; northern region of the State of Ceará the Acaraú River rises in the Serra das Matas, in the central-west region, at elevations greater than $800 \mathrm{~m}$ and developed practically in the north direction for $315 \mathrm{~km}$. The irrigation water is collected from the Santa Rosa dam from Acaraú's river, the second Salinity Laboratory in the United States, based on Electrical Conductivity (CE), as an indicator of the danger of soil salinization, and the Sodium Adsorption Ratio (RAS), as an indicator of danger of 


\section{Macrothink}

alkalization or soil sodification, the water used in this experiment was classified as: C2S1, that is, the low risk of salinity and does not offer a risk of sodicity. The climate of the region is classified as rainy tropical (Aw'), with average annual precipitation of $900 \mathrm{~mm}$, concentrated in the months from February to May. However, the region has undergone long periods of drought, with $51.7 \%$ of precipitations below normal averages in the last four years. The average annual temperature is $28{ }^{\circ} \mathrm{C}$ and the relative humidity is around $75 \%$. The soil of the region was classified as sandy Neossolo Quartzarênico (Entisol), with 79.1\% sand, 1.0\% silt and $11.3 \%$ clay, on a relief characterized by a gently undulating topography (EMBRAPA, 2007).

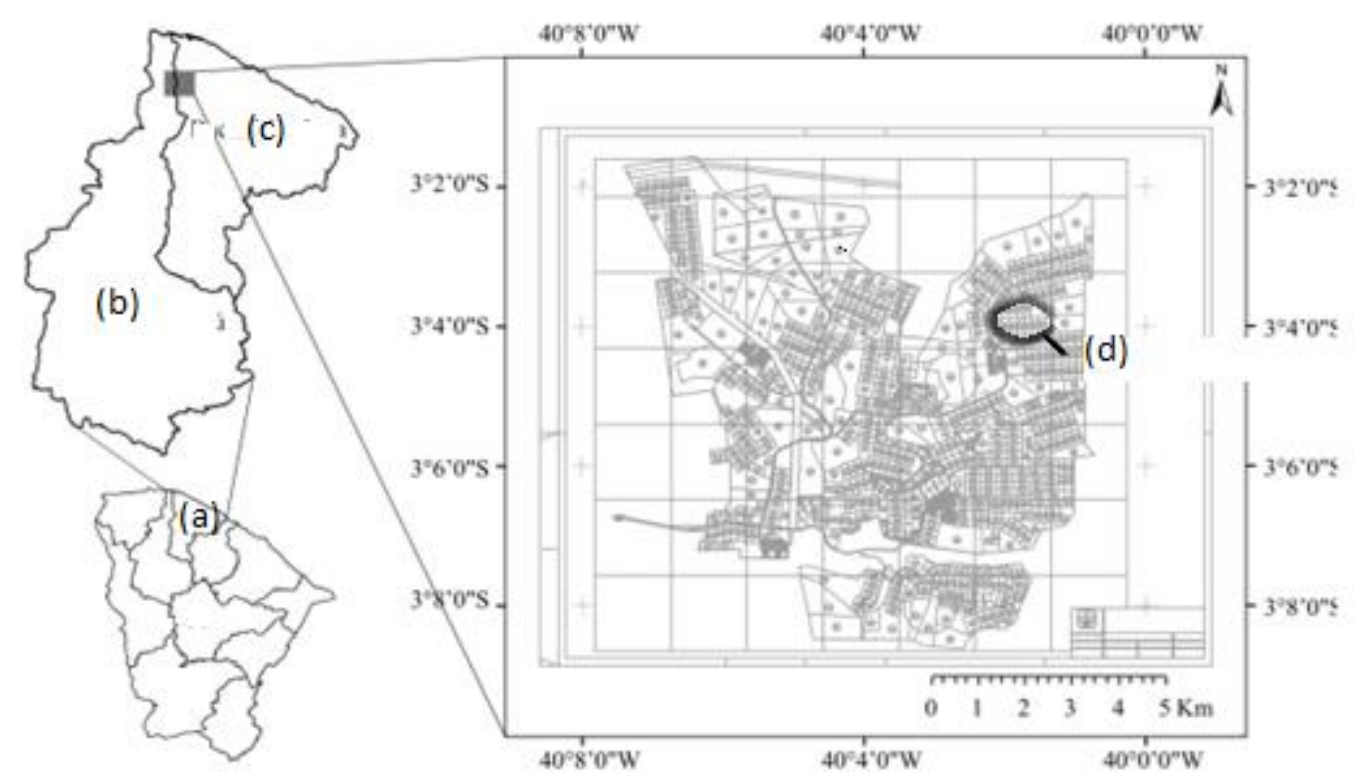

Figure 1. Region and irrigated perimeter where the experiment was carried out Fonte:

(Caitano et al., 2011)

\subsection{Field Experiments}

Two experiments were conducted with the watermelon crop, Explorer F1 hybrid variety, $c v$. Crimson Sweet. The first one from October to December 2013 (65 days) and the second one from July and August 2014 (56 days).

Cultivation was carried out with spacing of $4.0 \mathrm{~m}$ between rows and $1.0 \mathrm{~m}$ between plants $\left(2,500\right.$ plants $\left.\mathrm{ha}^{-1}\right)$ and sowing at depth from 2 to $3 \mathrm{~cm}$, as performed by the producers of the region. Fertilization was carried out directly in the hole, using $200 \mathrm{~g}^{\text {plant }}{ }^{-1}$ of $\mathrm{P}_{2} \mathrm{O}_{5}, 16 \mathrm{~g}$ plant ${ }^{-1}$ of $\mathrm{KCl}$ and $18 \mathrm{~g}$ plant $^{-1}$ of urea, based on soil chemical analysis $\left(\mathrm{Al}: 0.1 \mathrm{cmol}_{\mathrm{c}} \mathrm{dm}^{-3}\right.$; Ca: $1.7 \mathrm{cmol}_{\mathrm{c}} \mathrm{dm}^{-3} ; \mathrm{Mg}: 1.2 \mathrm{cmol}_{\mathrm{c}} \mathrm{dm}^{-3} ; \mathrm{K}: 0.11 \mathrm{cmol}_{\mathrm{c}} \mathrm{dm}^{-3} ; \mathrm{P}: 6.0 \mathrm{Mg} \mathrm{kg}^{-1}$ ), relative to the 0-0.30 m layer, and the nutritional needs of the crop (Rodrigues, 2013). In addition, top-dressing fertilization was performed by fertigation, every two days, totaling $62 \mathrm{~g} \mathrm{plant}^{-1}$ of $\mathrm{KCl}, 49 \mathrm{~g}$ plant $^{-1}$ of urea, $6 \mathrm{~g} \mathrm{plant}^{-1}$ of zinc and $10 \mathrm{~g}$ plant ${ }^{-1}$ of FTE BR. Phytosanitary 
treatments were performed in both cultivation periods.

The cultivation area had a drip irrigation system, with two drippers per plant, spaced by $0.5 \mathrm{~m}$, totaling a nominal flow rate of $3.0 \mathrm{~L} \mathrm{~h}^{-1}$ and average service pressure of $180 \mathrm{kPa}$. The water depths were split and applied twice a day in the initial stage and three times a day in the periods of highest demand by the crop. Polyethylene lateral lines, with $16 \mathrm{~mm}$ diameter and $112 \mathrm{~m}$ length, were supplied by 50-mm-diameter PVC main lines.

The experimental design was a randomized complete block with 7 plots per block (6 treatments with water deficit and one control) and 4 replicates, totaling 28 experimental plots, 50 meters long, with a useful experimental area of 5,600 $\mathrm{m}^{2}$. The irrigation system was previously evaluated in the field, under normal operating conditions. The amount of water applied was determined by the need to replace losses resulting from crop evapotranspiration (ETc), taking into account point irrigation. The reference evapotranspiration (ETo) estimate was made from daily evaporation readings made available by the local INMet weather station. The different irrigation blades applied in the plots were determined through the replacement calculation. To determine the irrigation schedule, the program was first calibrated for local conditions with data provided in the literature. In the field, a water deficit was applied with 3 treatments consisting of irrigation depths varying from $70 \%$ to $90 \%$ of (ETa / ETm) in a constant way throughout the watermelon culture cycle (CDI), and 3 treatments obeying the same total deficit, but concentrating the deficit in the least sensitive stages of the culture (Ky II and Ky IV), and the control treatment (SAI) which consists of applying $100 \%$ of the previous day's evapotranspirated lamina.

\subsection{Optimization of the Regulated Deficit Irrigation Strategy (ORDI)}

The water depths applied in the treatments were obtained by the MOPECO model, which employs the equation of Stewart et al. (1977) and the FAO-56 methodology (Allen et al., 1998) adapted by Domínguez et al. (2011), for estimating crop yield as a function of the actual versus maximum evapotranspiration ratio $\left(\mathrm{ET}_{\mathrm{a}} / \mathrm{ET}_{\mathrm{m}}\right)$ in the different growth stages. When $\mathrm{ET}_{\mathrm{a}}<\mathrm{ET}_{\mathrm{m}}$, the plant suffers from any stress that may cause a drop in yield (actual yield $\left(\mathrm{Y}_{\mathrm{a}}\right)<$ potential yield $\left.\left(\mathrm{Y}_{\mathrm{m}}\right)\right)$.

$$
Y_{a}=Y_{m} \prod_{k=1}^{3}\left(1-K_{y_{k}}\left(1-\frac{E T_{a_{k}}}{E T_{m_{k}}}\right)\right)
$$

where $\mathrm{Y}_{\mathrm{a}}$ and $\mathrm{Y}_{\mathrm{m}}$, actual and potential crop yields $\left(\mathrm{kg} \mathrm{ha}^{-1}\right)$; $\mathrm{k}$, actual growing stage (Allen et al., 1998); $\mathrm{K}_{\mathrm{yk}}$, crop yield response factor by growing stage; $\mathrm{ET}_{\mathrm{a}}$ and $\mathrm{ET}_{\mathrm{m}}$, accumulated crop evapotranspiration in each $\mathrm{K}_{\mathrm{y}}$ growing stage $(\mathrm{mm})$.

Water deficit treatments were applied according to the optimized regulated deficit irrigation (ORDI) methodology (Domínguez et al., 2012), which establishes irrigation strategies for each crop development stage, aiming at obtaining the highest possible yield for a given deficit proposed $\left(\mathrm{ET}_{\mathrm{a}} / \mathrm{ET}_{\mathrm{m}}\right.$ ratio). During the highest stress treatments, supplying a greater amount of water during $\mathrm{K}_{\mathrm{c}}$ (I) may be considered for improving nascence and crop 
establishment, then increasing stress once the crop is in the crop development stage $\left(\mathrm{K}_{\mathrm{c}}(\mathrm{II})\right)$. Conservative values for a stage $\mathrm{ET}_{\mathrm{a}} / \mathrm{ET}_{\mathrm{m}}$ target rate $\geq 0.8$ during $\mathrm{K}_{\mathrm{c}}$ (I) may be suitable, which is consistent with the strategies of avoiding high stress during the first stage but not during vegetative development The $\mathrm{K}_{\mathrm{y}}$ (i) stage includes $\mathrm{K}_{\mathrm{c}}$ (I) and $\mathrm{K}_{\mathrm{c}}$ (II) (Fig. 1).

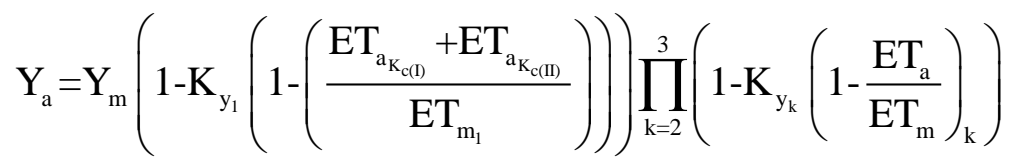

The term $\mathrm{ET}_{\mathrm{a}}$ refers to crop evapotranspiration under water deficit conditions, whereas $\mathrm{ET}_{\mathrm{m}}$ refers to evapotranspiration under optimum growing conditions (Allen et al., 1998).

The ORDI methodology requires a set of restrictions to avoid unacceptable results from the physiological point of view and/or an overestimated yield. Thus, the ETa $/ \mathrm{ET}_{\mathrm{m}}$ ratio in each stage should be $\geq 0.5$ (Allen et al., 1998), because the level of water stress applied in a given stage affects crop development in the next stage and, consequently, its final yield (Doorenbos $\&$ Kassam, 1979). Therefore, the treatments were characterized by management with ORDI $\left(70,80,90 \%\right.$ of $\mathrm{ET}_{\mathrm{a}} / \mathrm{ET}_{\mathrm{m}}$ ratio), management with constant deficit irrigation (CDI) along the entire cycle $\left(70,80\right.$ and $90 \%$ of $\left.\mathrm{ET}_{\mathrm{m}}\right)$ and a control treatment, irrigated with $100 \%$ of the water depth required by the crop (ETm).

Daily ET $_{m}$ was calculated using the equation proposed by Doorenbos and Pruitt (1977) (ET $_{m}$ $=\mathrm{K}_{\mathrm{c}} \mathrm{ET}_{\mathrm{o}}$ ), while daily $\mathrm{ET}_{\mathrm{a}}$ under water and/or salinity stress conditions is calculated using the equation proposed by Allen et al. (1998), which requires a daily balance of water and salt content in the soil (Domínguez et al., 2011).

As input data, the model uses the potential yield of watermelon cultivation for the region (Ym $=40,000 \mathrm{~kg} \mathrm{ha}^{-1}$ ) (Miranda et al., 2004), the accumulated evapotranspiration in each phenological stage: establishment (i), flowering (ii), fruit formation (iii) and maturation (iv); crop coefficient $(\mathrm{Kc})$ and yield response factor to water deficit $(\mathrm{Ky})$ for each phenological stage; and the desired stress ratios $(\mathrm{ETa} / \mathrm{ETm})$, which are used in the schedules of management with CDI.

The crop coefficients (Kc) obtained by Miranda et al. (2004) and yield response factor to water deficit (Ky) suggested by Doorenbos \& Kassam (1979) were used, according to Figure 1. 


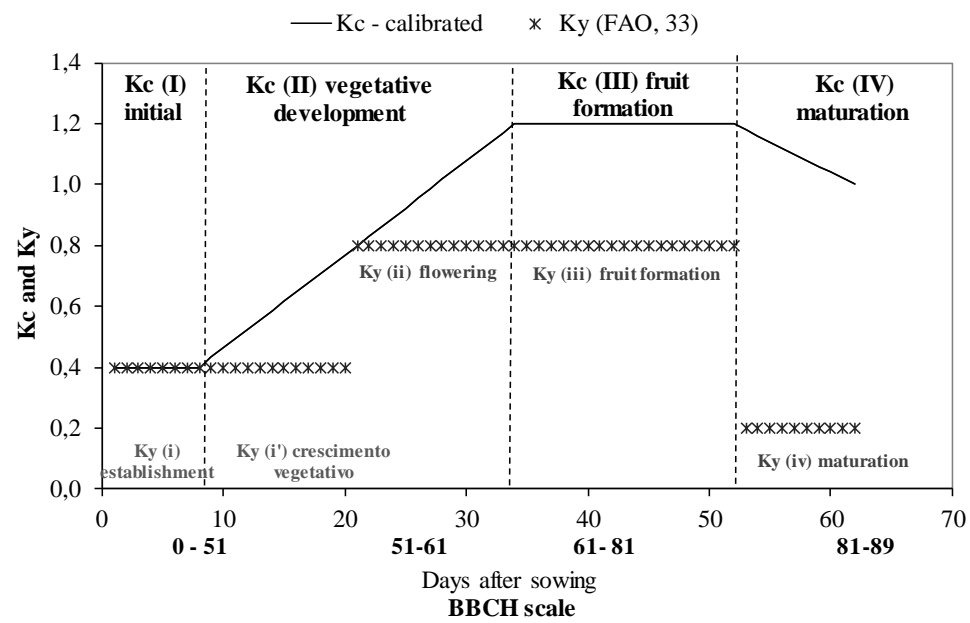

Figure 2. Evolution of crop coefficient (Kc) and yield response factor to water deficit (Ky) calibrated for watermelon cultivation in Ceará, Brazil

\subsection{Effect of Inter-Annual Variability on Crop Growth}

For the calibration of the stages of $\mathrm{Kc}$ and $\mathrm{ky}$, some articles made in semiarid region (BASTOS et al., 2007; FIGUEIREDO et al., 2007; MIRANDA et al., 2004) were selected and the phenological stages were calculated in degrees days, the moment end and beginning of the stages were determined using the BBCH scale (NOVARTIS, 1998).

Table 1. Average duration of the phenological stages of Kc and Ky

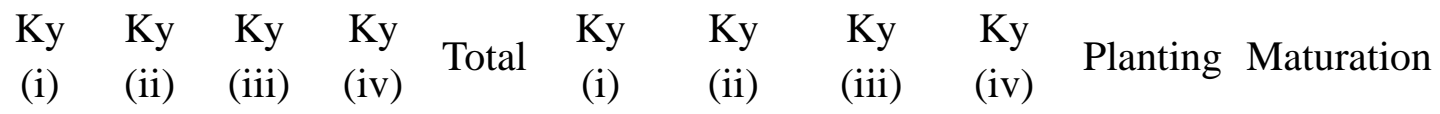

\begin{tabular}{llllllllll}
\hline Initial & 0 & 51 & 61 & 81 & 0 & 0 & 51 & 61 & 81 \\
End & 51 & 61 & 81 & 89 & 89 & 51 & 61 & 81 & 89 \\
\hline
\end{tabular}

Day Julian growth day

\begin{tabular}{lllllllllllll}
\cline { 3 - 4 } & 18 & 20 & 18 & 7 & 63 & 185 & 717 & 1046 & 1159 & 29 ago. & 23 nov. \\
2008 & 21 & 19 & 18 & 5 & 63 & 174 & 637,1 & 893 & 991 & 10 dez. & 11 fev. \\
2009 & 20 & 19 & 16 & 5 & 60 & 164 & 703 & 1017 & 1171 & 11 abr. & 10 jun. \\
Media & 20 & 19 & 17 & 6 & 62 & 123 & 686 & 986 & 1107 & &
\end{tabular}

To obtain the length of watermelon growth stages in terms of accumulated GDD, MOPECO 
uses the double triangulation method (Sevacherian et al., 1977; Domínguez et al., 2012a). Two parameters must be determined for the GDD calculation: $\mathrm{T}_{\mathrm{L}}$ (lower threshold temperature for development, in ${ }^{\circ} \mathrm{C}$ ) and $\mathrm{T}_{\mathrm{U}}$ (upper threshold temperature at which the rate of development begins to decrease, in ${ }^{\circ} \mathrm{C}$ ). This methodology requires a $\mathrm{T}_{\mathrm{U}}$ value, which was assumed to be $40^{\circ} \mathrm{C}$, higher than the maximum temperature in the area. Watermelon phenological stages were calibrated for the local climatic conditions and represented in growing-degree-days (GDD), taking as reference the decimal code for the phenological stages of monocotyledons and dicotyledons (Bleiholder, 2001). The accumulated GDD values and cycle day corresponding were: 123 and 20 (initial stage), 686 and 19 (vegetative development stage), 986 and 17 (fruit formation stage), and 1107 and 6 (maturation stage).

The irrigation schedules were estimated using the climatological historical series provided by INMET, adapted to the methodology of the typical meteorological year, developed by Leite et al. (2015a).

Harvest was performed at 65 days after sowing (DAS) in the first experiment and at 56 DAS in the second experiment. At harvest, fruit maturation was detected based on field indicators: soluble solids around $12^{\circ}$ Brix, pulp firmness, color and appearance of fruit rind. Harvest was performed manually, with scissors, keeping the stalk with 1 to $3 \mathrm{~cm}$ in length. Fruits of three plants of each plot were collected, properly labeled and then transported to the Postharvest Laboratory of the Federal Institute of Ceará - Sobral, where they were evaluated for: average fruit weight $(\mathrm{kg})$, average yield $\left(\mathrm{kg} \mathrm{ha}^{-1}\right)$ and average diameter $(\mathrm{mm})$ the fruits of each treatment.

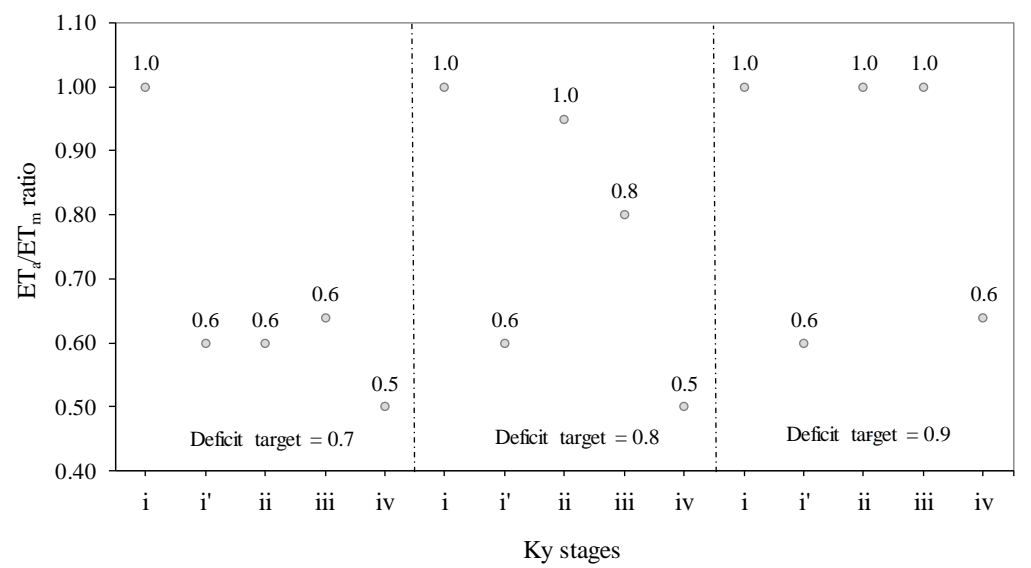

Figure 3. ETa/ETm ratios for the optimized regulated deficit irrigation (ORDI) applied during the watermelon phenological cycle for the different treatments evaluated

Data of each production variable were subjected to homoscedasticity test and, after being checked for normality, to analysis of variance at $5 \%$ probability level $(\mathrm{p}<0.05)$ by $\mathrm{F}$ test. When significant, equations were fitted by regression analysis, selecting the models with best levels of significance and coefficient of determination $\left(\mathrm{R}^{2}\right)$.

Irrigation water use efficiency (WUE) was calculated by the ratio between watermelon yield and the total water volume applied along its cycle for each treatment. Finally, an economic 
analysis was carried out using product price and orchard planting cost of $\mathrm{R} \$ 0.15 \mathrm{~kg}^{-1}$ and $\mathrm{R} \$ 3,671.60 \mathrm{ha}^{-1}$, respectively (EMATERCE, 2017). The cost of water ( $\mathrm{R} \$ \mathrm{~L}^{-1}$ ) was considered to be equal to the value of the electricity tariff, since the costs of application were included in the cost of production, according to Frizzone et al. (1997). The price of kWh ( $\mathrm{R} \$$ 0.26) was set according to the Electric Power Distribution Company of Ceará (COELCE) considering peak hours, that is, daytime irrigation. The equation generated by the cost of planting the crop and variable water cost for the different quantities of water applied was used to calculate the net revenue for each yield obtained in the different treatments.

\section{Results and Discussion}

The values of evapotranspiration accumulated along the experiments were slightly higher than those simulated in the model calibration (4\% in 2013 and 2\% in 2014), indicating the accuracy of the irrigation schedule by the MOPECO crop simulation model associated with the typical meteorological year (TMY) methodology (LEITE et al., 2015b). Due to the small difference in the duration of the cycles and to the meteorological characteristics in both periods of cultivation (Table 2), the difference of GDD between the crops was 227.5, evidencing that the thermal sum of each phenological stage of the watermelon crop may vary with sowing time (Streck et al., 2009). In the first experiment, the thermal accumulation was slightly higher and, in the second one, slightly lower than the average phenological cycle of watermelon estimated in the present study. However, the 5\% variation between the phenological stages estimated and evaluated in the experiments was within the acceptable range, according to Trentin et al. (2008). By means of field experiments and different methods of calculation, the authors evaluated the thermal time of three developmental sub-periods of watermelon plants and obtained similarity $\left(417^{\circ} \mathrm{C}\right.$ day) from 98 to $130^{\circ} \mathrm{C}$ between them.

Watermelon is a megathermal crop and its climatic requirements are similar to those of melon, but it is slightly more demanding in terms of temperature. Plant growth is more active at temperatures above $15^{\circ} \mathrm{C}$, but the best temperature range is from 25 to $30^{\circ} \mathrm{C}$ (Trentin et al., 2008), consistent with the climatic conditions observed in field experiments.

Table 2. Characterization of watermelon development stages for the 2013 and 2014 crop 
cycles

\begin{tabular}{cccccc}
\hline \multirow{2}{*}{$\begin{array}{c}\text { Stages } \\
(\mathrm{Kc})\end{array}$} & Start & End & $\begin{array}{c}\text { Duration } \\
\text { (Days) }\end{array}$ & $\begin{array}{c}\text { Accumulated } \\
\text { degree-days }\end{array}$ & $\begin{array}{c}\text { ETo } \\
(\mathrm{mm})\end{array}$ \\
\cline { 2 - 4 } & \multicolumn{5}{c}{2013} \\
\hline Initial & $10 / 29 / 2013$ & $11 / 07 / 2013$ & 9 & 176.10 & 40.6 \\
Vegetative & $11 / 08 / 2013$ & $11 / 24 / 2013$ & 22 & 600.40 & 90.3 \\
Medium & $11 / 25 / 2013$ & $12 / 22 / 2013$ & 27 & 1128.43 & 109.1 \\
Final & $12 / 23 / 2013$ & $12 / 30 / 2013$ & 7 & 1247.93 & 15.2 \\
\hline TOTAL & & & 65 & 1247.93 & 255.2 \\
\hline & & 2014 & & & \\
\hline Initial & $07 / 02 / 2014$ & $07 / 11 / 2014$ & 9 & 160.43 & 43.0 \\
Vegetative & $07 / 12 / 2014$ & $07 / 31 / 2014$ & 19 & 495.7 & 92.8 \\
Medium & $08 / 01 / 2014$ & $08 / 23 / 2014$ & 23 & 913.85 & 94.2 \\
Final & $08 / 24 / 2014$ & $09 / 28 / 2014$ & 7 & 1020.4 & 18.3 \\
\hline TOTAL & & & 56 & 1020.4 & 248.3 \\
\hline
\end{tabular}

The average fruit weight and diameter did not differ statistically between treatments. In the second experiment (2014), the average fruit weight was $11.8 \mathrm{~kg}$ and the average diameter was $352 \mathrm{~mm}$. Miranda et al. (2005) evaluated the production of watermelon, cv. Crimson Sweet, under drip irrigation at different spacings between plants in Paraipaba-CE and found that planting density significantly affected the number of fruits per plant and their average weight. Fruits with average weight of $9.0 \mathrm{~kg}$ were obtained with the larger spacing of $2 \mathrm{x} 1 \mathrm{~m}$ and one plant per hole. The spacings with two plants per hole $(2.0 \times 1.0 \mathrm{~m}$ and $2.0 \times 1.5 \mathrm{~m}) \mathrm{can}$ be recommended for markets with preference for medium-sized fruits. However, in the first experiment, the data showed variation in fruit diameter of $272.1 \mathrm{~mm}$ in the treatment without deficit, 260.9, 247.1 and $196.2 \mathrm{~mm}$ in CDI treatments, and 263.2, 260.6 and $233.5 \mathrm{~mm}$ in ORDI treatments, for water supplies of 90,80 and $70 \%$, respectively. It can be noted that, for both management strategies evaluated, there was decreasing effect on fruit diameter, but the values associated with the ORDI methodology were higher than those obtained with CDI. According to Costa et al. (2013), fruit diameter is a direct indicator of fruit size. These variables are important in the selection of fruits for the market of fresh fruits, since larger fruits are more valued for the domestic market, while the export market prefers smaller fruits (Sousa et al., 2016).

The yield obtained in 2013 was lower than that obtained in 2014, which can be attributed to the incidence of pests and diseases that interfered in the active development of the crop in 2013. This difference was also observed between ORDI and CDI treatments for that year, according to (Taiz; Bleing 2016), when the plant suffers from extreme factors of attack by pests and diseases, it tends to create physiological defense mechanisms, however the controlled deficit irrigation ORDI may have attenuated the stress suffered by adverse factors thus promoting a greater difference between the methodologies. (Table 3)

Despite that, the yield was similar to the maximum value obtained by Miranda et al. (2004) 
(38.0 Mg ha-1). It is worth pointing out that a value of $40,000 \mathrm{~kg} \mathrm{ha}^{-1}$ was used in the calibration of the model (MOPECO) as the crop potential yield for the region (Melo et al., 2011).

The results (experiment 2) indicate a decrease in watermelon yield with the reduction in the volume applied, evidencing that the calibration and validation carried out by MOPECO model generate an optimized irrigation management, thus reducing water costs during the production cycle (Leite et al., 2015b). The yield corresponding to the ORDI methodology was higher than that obtained with the CDI in all phenological stages of the crop. Watermelon has a direct response to the water factor in terms of fruit weight and yield (Kusçu et al., 2015).

Table 3. Total yield of watermelon $\left(\mathrm{kg} \mathrm{ha}^{-1}\right)$ in 2013 and 2014 under different water volumes applied per plant and water deficit application methodologies

\begin{tabular}{|c|c|c|c|c|c|c|}
\hline \multirow{3}{*}{$\begin{array}{c}\text { Ratio } \\
\left(\mathrm{ET}_{\mathrm{a}} / \mathrm{ET}_{\mathrm{m}}\right)\end{array}$} & \multicolumn{3}{|c|}{2013} & \multicolumn{3}{|c|}{2014} \\
\hline & \multirow{2}{*}{$\begin{array}{l}\text { Irrigation* } \\
\left(\text { L plant }^{-1}\right)\end{array}$} & \multicolumn{2}{|c|}{ Yield $\left(\mathrm{kg} \mathrm{ha}^{-1}\right)$} & \multirow{2}{*}{$\begin{array}{l}\text { Irrigation } \\
\left(\mathrm{L}_{\text {plant }}{ }^{-1}\right)\end{array}$} & \multicolumn{2}{|c|}{ Yield $\left(\mathrm{kg} \mathrm{ha}^{-1}\right)$} \\
\hline & & CDI & ORDI & & CDI & ORDI \\
\hline 1.0 & 549.3 & \multicolumn{2}{|c|}{$36,666.6 \mathrm{~A}$} & 503.6 & \multicolumn{2}{|c|}{$39,108.8 \mathrm{~A}$} \\
\hline 0.9 & 453.3 & $27,076.3 \mathrm{~B} \mathrm{~g}$ & $35,265.7 \mathrm{~B} \mathrm{f}$ & 452.7 & $38,074.4 \mathrm{~B} \mathrm{~g}$ & $39,382.0 \mathrm{~A} \mathrm{f}$ \\
\hline 0.8 & 439.3 & $25,415.0 \mathrm{C} \mathrm{i}$ & $31,915.7 \mathrm{Ch}$ & 402.4 & $36,964.2 \mathrm{C} \mathrm{i}$ & $37,707.2 \mathrm{~B} \mathrm{~h}$ \\
\hline 0.7 & 399.8 & $19,210.5 \mathrm{D} \mathrm{k}$ & $25,208.2 \mathrm{D} \mathrm{j}$ & 352.1 & $36,776.5 \mathrm{Cj}$ & $36,790.3 \mathrm{Cj}$ \\
\hline $\mathrm{CV} \%$ & & 4.386 & & & 3.452 & \\
\hline
\end{tabular}

Means followed by the same uppercase letter in the same column and lowercase letter in the same row, for the same experimental year, do not differ statistically at $5 \%$ probability level

* Water applied via irrigation, there was no precipitation in the period.

In the first experiment, the maximum yield (36.67 $\mathrm{Mg} \mathrm{ha}^{-1}$ ) was obtained in the control treatment, with irrigation management without deficit $\left(\mathrm{ET}_{\mathrm{a}} / \mathrm{ET}_{\mathrm{m}}=1.0\right)$, followed by the phase-optimized irrigation management $\left(35.26 \mathrm{Mg} \mathrm{ha}^{-1}\right.$ ), supplying $90 \%$ of crop water requirement (ORDI - 0.9). The lowest yield was obtained with the CDI treatment (0.7), as a consequence of the physiological defense mechanism of the plant. Under severe water deficit, the plant accelerates its metabolism in order to complete its cycle before reaching the permanent wilting point, causing an increase in the number of fruits and decrease in size (Orta et al., 2003). Teodoro et al. (2004) worked with irrigation depths in the watermelon crop and reported that yield was influenced by water scarcity in soil, with positive linear 
response from the lowest $(118.6 \mathrm{~mm})$ to the highest $(442.0 \mathrm{~mm})$ water depth applied. Evaluating watermelon ( $c v$. Crimson Sweet) yield in response to different levels of water deficit in Turkey, Kirnak \& Dogan (2009) obtained maximum yield (35 $\mathrm{Mg} \mathrm{ha}^{-1}$ ) in the treatment that applied $100 \% \mathrm{ET}_{\mathrm{m}}$. These results corroborate those reported by Teodoro et al. (2004), who found that watermelon yield was significantly affected by water deficit in soil, especially in the stages of flowering, fruiting and fruit development.

The highest yield of watermelon in the second experiment (39.38 $\mathrm{Mg} \mathrm{ha}^{-1}$ ) was obtained using the ORDI methodology with $\mathrm{ET}_{\mathrm{a}} / \mathrm{ET}_{\mathrm{m}}$ ratio of 0.9 , a statistically similar value to that obtained in the control treatment $\left(39.11 \mathrm{Mg} \mathrm{ha}^{-1}\right)$. The obtained yield was slightly lower than those obtained by Teodoro et al. (2004), evaluating the yield of watermelon ( $c v$. Crimson Sweet) subjected to water depths ranging from 20 to $125 \%$ of Class A pan evaporation, in the municipality of Uberlândia-MG. In the highest water depth applied, the yield reached 44.96 $\mathrm{Mg} \mathrm{ha}^{-1}$, which is close to that found by Sandri et al. (2014) (46.27 $\mathrm{Mg} \mathrm{ha}^{-1}$ ), when evaluating the response of watermelon subjected to full water supply in the region of Anápolis - GO.

The ORDI methodology is extremely important in terms of water saving. In 2014, the treatments supplying 90,80 and $70 \%$ of the crop water requirement $\left(\mathrm{ET}_{\mathrm{a}} / \mathrm{ET}_{\mathrm{m}}=0.9 ; \mathrm{ET}_{\mathrm{a}} / \mathrm{ET}_{\mathrm{m}}\right.$ $\left.=0.8 ; \mathrm{ET}_{\mathrm{a}} / \mathrm{ET}_{\mathrm{m}}=0.7\right)$ stood out among the different methodologies, leading to differences close to $1,000 \mathrm{~kg} \mathrm{ha}^{-1}$ between the ORDI and CDI strategies, which significantly interfered with net revenue and water use efficiency (Figure 3). Evaluating watermelon yield under conditions of constant deficit irrigation in each stage and levels of potassium fertilization, Oliveira et al. (2012) obtained yields ranging from 15.0 to $30.0 \mathrm{Mg} \mathrm{ha}^{-1}$ with water volumes of 500 to $2,700 \mathrm{~m}^{3} \mathrm{ha}^{-1}$. Batista et al. (2008) obtained maximum yield of $44.46 \mathrm{Mg} \mathrm{ha}^{-1}$ when applying $120 \%$ of the volume evapotranspired by Crimson Sweet watermelon under drip irrigation.

The results of yield related to the water volumes applied for the two years of cultivation allowed the fitting of a quadratic polynomial model (Eqs. 3 to 6), which had the highest level of significance and higher coefficient of determination, according to Morais et al. (2008).

$$
\begin{array}{ll}
Y_{\text {CDI-2013 }}=0.3755 \mathrm{~V}^{2}-247.38 \mathrm{~V}+58,623 & \left(\mathrm{R}^{2}=0.95\right) \\
\mathrm{Y}_{\text {ORDI-2013 }}=-0.4911 \mathrm{~V}^{2}+542.44 \mathrm{~V}-113,130 & \left(\mathrm{R}^{2}=0.99\right) \\
\mathrm{Y}_{\text {CDI-2014 }}=0.0818 \mathrm{~V}^{2}-53.933 \mathrm{~V}+45,574 & \left(\mathrm{R}^{2}=0.91\right) \\
\mathrm{Y}_{\text {ORDI-2014 }}=-0.1180 \mathrm{~V}^{2}+118.07 \mathrm{~V}+9,712.5 & \left(\mathrm{R}^{2}=0.98\right)
\end{array}
$$

where $\mathrm{Y}$, watermelon yield $\left(\mathrm{kg} \mathrm{ha}^{-1}\right)$ and $\mathrm{V}$, water volume applied through irrigation (L).

The maximum net revenue (Figure 4) was obtained in the treatment with $90 \%$ of crop water requirement in $2014\left(2,156.00 \mathrm{R} \$ \mathrm{ha}^{-1}\right)$ by the ORDI methodology, followed by the treatment 
without water deficit. Although the WUE is high at the lowest water supply for both methodologies (ORDI and CDI), the net revenue obtained by the increased use of water in the production becomes an incentive to the use of deficit irrigation, even in Brazil, where the cost of water for irrigation is low. In this case, irrigation schedules using regulated water deficit with $70 \%$ water supply should be adopted in watermelon cultivation only as an alternative in cases of extreme water scarcity.
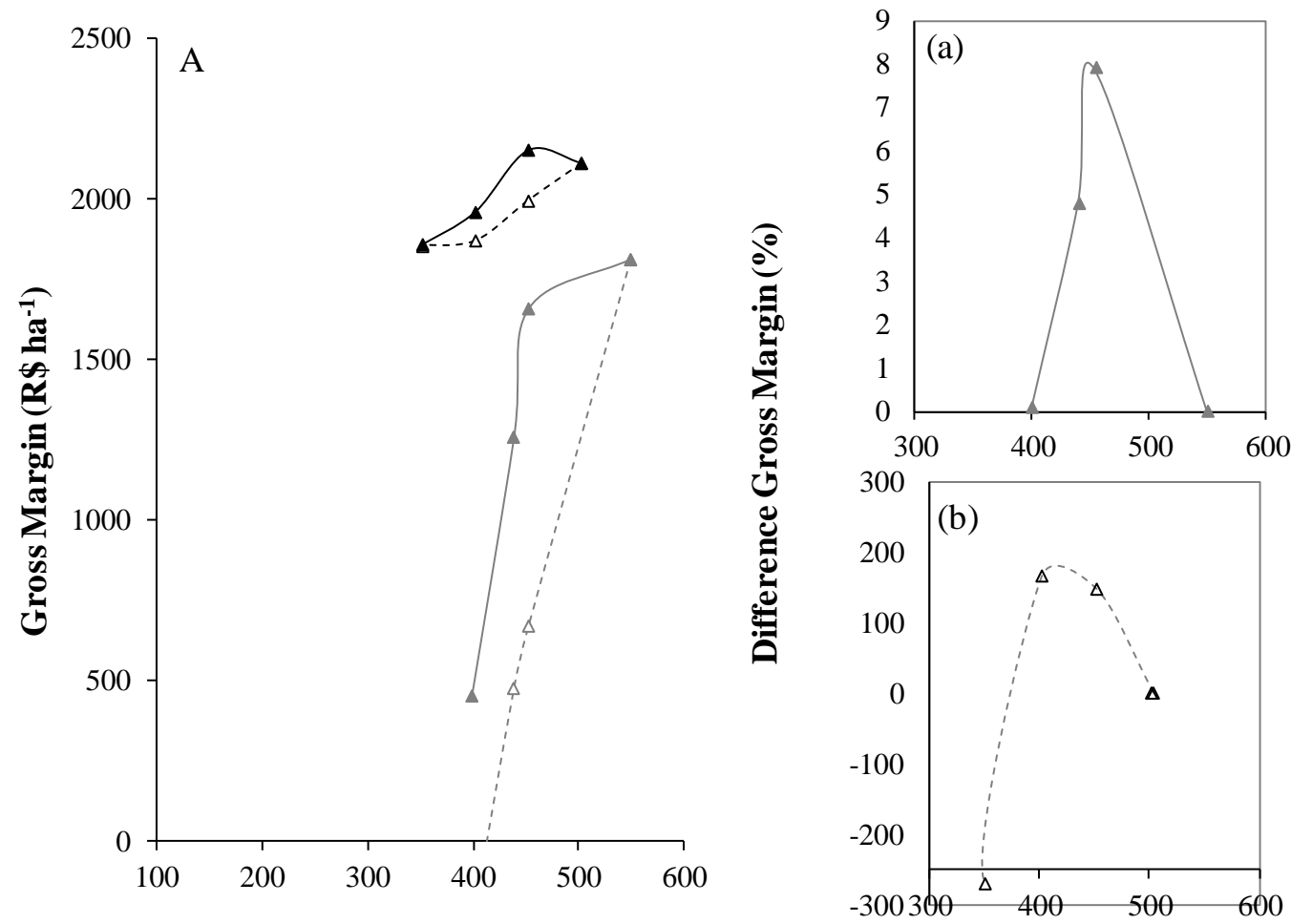

Gross Irrigation+ Rainfall (L)

$-\triangleleft-$ CDI - $2014 \multimap$ ORDI - $2014-\triangleleft-$ CDI - $2013 \multimap-$ ORDI - 2013

Figure 4. Gross Margin (A) and difference gross margin and the methodology (\%) (a) 2013 and (b.) 2014

In terms of water saving, especially in a situation of severe water scarcity, irrigation management with regulated water deficit (ORDI) can provide favorable and economically viable results for the farmer. The highest value of WUE $\left(41.8 \mathrm{~kg} \mathrm{~m}^{-3}\right)$ was obtained with the treatment of lowest water volume applied $(352.1 \mathrm{~L})$ in the second experiment, decreasing with the increase in the water volume used (Figure 5A). A similar result was observed by Oliveira et al. (2012), who found that the maximum WUE $\left(33.34 \mathrm{~kg} \mathrm{~m}^{-3}\right)$ also corresponded to the lowest water volume applied. Melo et al. (2011) evaluated watermelon yield under different water levels and observed maximum efficiency of $19.6 \mathrm{~kg} \mathrm{~m}^{-3}$ when a $266 \mathrm{~mm}$ water depth was applied along the entire cycle. 

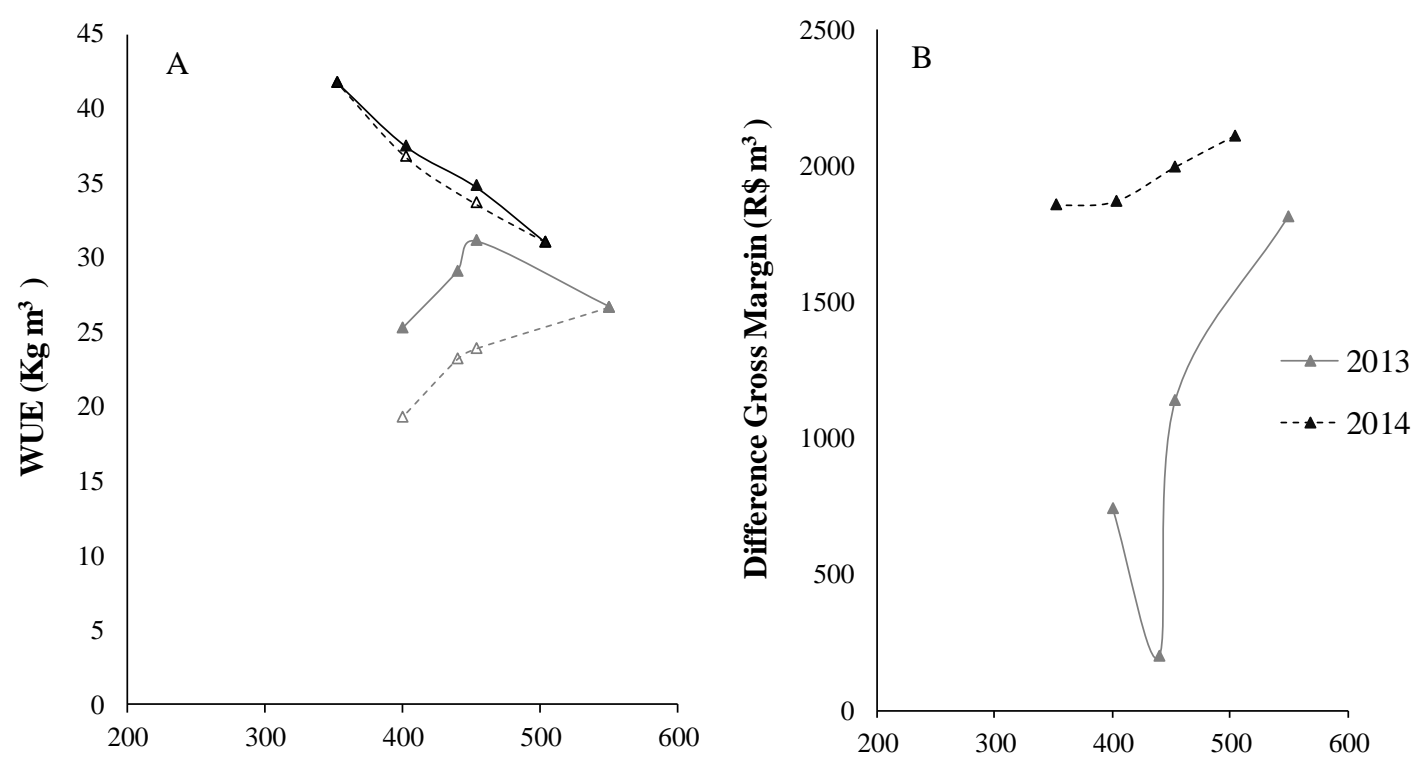

Gross Irrigation+ Rainfall (L)

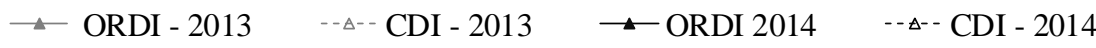

Figure 5. (A) Efficiency of water use for different methodologies (WUE) and (B) differentiation of Gross Margin obtained with different methodologies for the years 2013 and 2014

\section{Conclusions}

1. The ORDI methodology led to higher yield and water use efficiency in all ORDI treatments, compared to the CDI treatments.

2. MOPECO model proved to be adequate to simulate strategic schedules of regulated deficit irrigation.

3. Under limiting water conditions, the strategy with water supply of $70 \%$ of $\mathrm{ET}_{\mathrm{a}} / \mathrm{ET}_{\mathrm{m}}$ ratio regulated by phenological stage should be used in order to obtain highest water use efficiency.

\section{References}

Allen, R. G., Pereira, L. S., Raes, D., \& Smith, M. (1998). Crop evapotranspiration: Guidelines for computing crop water requirements. Rome: FAO, 1998. 300p. FAO Irrigation and Drainage Paper No. 56.

Andrade Júnior, A. S., Dias, N. S., Figueiredo Júnior, L. G. M., Ribeiro, V. Q., \& Sampaio, D. B. (2010). Produção e qualidade de frutas de melancia à aplicação de nitrogênio via fertilização. Revista Brasileira de Engenharia Agrícola e Ambiental, 10, 836-841. https://doi.org/10.1590/S1415-43662006000400008 
Batista, P. F., Karasawa, M., Silva, N. C. da, Pires, M. M. M. da L., Pimenta, R. M. B., \& Aragão, C. A. (2008). Produtividade da melancia irrigada por gotejamento submetida a diferentes espaçamentos e lâminas de irrigação. Horticultura Brasileira, 26, 706-709.

Bleiholder, H., Weber, E., Lancashire, P. D., Feller, C., Buhr, L., Hess, M., ... Stauss, R. (2001). Growth stages of mono-and dicotyledonous plants BBCH Monograph. 2.ed. Braunschweig, Germany: Ed. Meier, University Federal Biological Research Centre for Agriculture and Forestry. 158p.

Caitano, R. F., Lopes, F. B., Souza, F. de, \& Mendonça, M. A. B. (2011). Desempenho dos sistemas de irrigação na cultura da banana no perímetro irrigado baixo acaraú, ceará. Revista Brasileira de Agricultura Irrigada. https://doi.org/10.7127/rbai.v5n200051

Costa, A. R. F., Medeiros, J. F., Porto Filho, F. Q., Silva, J. S. da, Costa, F. G. B., Freitas, D. C. da. (2013). Produção e qualidade de melancia cultivada com água de diferentes salinidades e doses de nitrogênio. Revista Brasileira de Engenharia Agrícola e Ambiental, 17, 947-954. https://doi.org/10.1590/S1415-43662013000900006

Domínguez, A., Jiménez, M., Tarjuelo, J. M., de Juan, J. A., Martínez-Romero, A., \& Leite, K. N. (2012). Simulation of onion crop behavior under optimized regulated deficit irrigation using MOPECO model in a semi-arid environment. Agricultural Water Management, 113, 64-75. https://doi.org/10.1016/j.agwat.2012.06.019

Domínguez, A., Martínez-Romero, A., Leite, K. N., Tarjuelo, J. M., de Juan, J. A., \& López-Urrea, R. (2013). Combination of typical meteorological year with regulated deficit irrigation to improve the profitability of garlic growing in central spain. Agricultural Water Management, 130, 154-167. https://doi.org/10.1016/j.agwat.2013.08.024

Doorenbos, J., \& Kassam, A. H. (1979). Yield response to water. Italy: FAO, 1979. 201 p. Irrigation and Drainage Paper No. 33.

EMATERCE - Empresa de Assistência técnica e extensão rural do Ceará, 2017. Custo de Produção e exportação da melancia no Ceara. Disponível em: <https://www.ematerce.ce.gov.br.>. Acesso em: 01 de jun. 2017.

EMBRAPA - Empresa Brasileira de Pesquisa Agropecuária. Centro Nacional de Pesquisa de Solos (1997). Manual de métodos de análises de solos. 2. ed. Rio de Janeiro: Atual Embrapa-CNP Solos. 212p. Documentos, 1.

Frizzone, J. A., Coelho, R. D., Dourado-Neto, D., \& Soliani, R. (1997). Linear programming model to optimize the water resource use in irrigation projects: An application to the Senador Nilo Coelho Project. Scientia Agricola, 54, 136-148. https://doi.org/10.1590/S0103-90161997000300016

Kirnak, F., \& Dogan, E. (2009). Effect of seasonal water stress imposed on drip irrigated second crop watermelon grown in semi-arid climatic conditions. Irrigation Science, New York, 27(2), 155-164. https://doi.org/10.1007/s00271-008-0130-3

Kuşcu, H., Turhan, A., Özmen, N., Aydınol, P., Büyükcangaz, H., \& Demir, A. O. (2015). 
Deficit irrigation effects on watermelon (citrullus vulgaris) in a Sub humid environment. The Journal of Animal \& Plant Sciences, 25, 1652-1659.

Leite, K.N., Martínez-Romero, A., Tarjuelo, J. M., \& Domínguez, A. (2015). Distribution of limited irrigation water based on optimized regulated deficit irrigation and typical metheorological year concepts. Agricultural Water Management, 148, 164-176. https://doi.org/10.1016/j.agwat.2014.10.002

Leite, Kelly N., Cabello, M. J., Valnir Júnior, M., Tarjuelo, J. M., \& Domínguez, A. (2015). Modelling sustainable salt water management under deficit irrigation conditions for melon in Spain and Brazil. Journal of the Science of Food and Agriculture. https://doi.org/10.1002/jsfa.6951

Lucena, R. R. M., Negreiros, M. Z., Medeiros, J. F., Grangeiro, L. C., \& Marrocos, S. T. P., (2013). Crescimento e acúmulo de macronutrientes em melancia "Quetzale" cultivada sob diferentes níveis de salinidade da água de irrigação. Revista Caatinga, 24, 34-42.

Melo, T. K., Medeiros, J. F. de, Espínola Sobrinho, J., Figueirêdo, V. B., Pereira, V. C., \& Campos, M. S. (2011). Evapotranspiração e produção do melão Gália irrigado com água de diferentes salinidades e adubação nitrogenada. Revista Brasileira Engenharia Agrícola Ambiental, 15, 1235-1241. https://doi.org/10.1590/S1415-43662011001200004

Miranda, F. R., Montenegro, A. A. T., \& Oliveira, J. J. G. (2005). Produtividade da melancia irrigada por gotejamento em diferentes espaçamentos de plantio. Revista Ciência Agronômica, $36(2), 158-162$.

Miranda, F. R. de, Oliveira, J. J. G., \& Souza, F. de. (2004). Evapotranspiração máxima e coeficientes de cultivo para a cultura da melancia irrigada por gotejamento. Revista Ciência Agronômica, 35, 36-43.

Morais, N. B. de, Bezerra, F. M. L., Medeiros, J. F. de, \& Chaves, S. W. P. (2008). Resposta de plantas de melancia cultivadas sob diferentes níveis de água e de nitrogênio. Revista Ciência Agronômica, 39, 369-377.

Oliveira, P. G. F. de, Moreira, O. da C., Branco, L. M. C., Costa, R. N. T. \& Dias, C. N. (2012). Eficiência de uso dos fatores de produção água e potássio na cultura da melancia irrigada com água de reúso. Revista Brasileira de Engenharia Agrícola e Ambiental, 16, 153-158. https://doi.org/10.1590/S1415-43662012000200004

Orta, A. H., Erdem, Y., \& Erdem, T. (2003). Crop water stress index for watermelon. Science Horticulturae, 98, 121-130. https://doi.org/10.1016/S0304-4238(02)00215-7

Rodrigues, L. G. Transcrição de recomendação de adubação e calagem para o Estado do Ceará. Fortaleza: UFC, 1993. 2013 Universidade Federal do Ceará. 2013.

Sandri, D., Pereira J. A. Vargas R. B. et al. (2014). Custos de produção e rentabilidade produtiva da melancia sob diferentes lâminas e sistemas de irrigação. Irriga, Botucatu, 19(3), 414-429. https://doi.org/10.15809/irriga.2014v19n3p414 


\section{Macrothink}

Saraiva, K. R., Bezerra, F. M. L., Souza, F., \& Camboim Neto, L. de F. (2013). Using "ISAREG" on irrigation management in watermelon cultivation in the Baixo Acaraú. Ciência Agronômia, 44, 53-60. https://doi.org/10.1590/S1806-66902013000100007

Sousa, A. B. O. de, Duarte, S. N., Sousa Neto, O. N. de, Souza, A. C. M., Sampaio, P. R. F., \& Dias, C. T. S. (2012). Production and quality of mini watermelon cv. Smile irrigated with saline water. Revista Brasileira de Engenharia Agrícola e Ambiental, 20, 897-902. https://doi.org/10.1590/1807-1929/agriambi.v20n10p897-902

Steduto, P., Hsiao, T. C., Fereres, E., \& Raes D. Crop yield response to water. Rome: FAO, 500p. FAO Irrigation and Drainage Paper 66.

Stewart, J. I., Hagan, R. M.; Pruitt, W. O., Kanks, R. J., Riley, J. P., Danilson, R. E., ... Jackson, E. B. (1997). Optimizing crop production through control of waterand salinity levels. Utah, USA: Utah Water Res. Lab. 1977. 191p. PWRG 151-1.

Streck, N. A., Paula, G. M. de, Oliveira, F. O., Schwantes, A. P., \& Menezes, N. L. de. (2009). Improving node number simulation in soybean. Pesquisa Agropecuária Brasileira, 44, 661-668. https://doi.org/10.1590/S0100-204X2009000700002

Teodoro, R. E. F., Almeida, F. P., Luz, J. M. Q., \& Melo, B. (2004). Diferentes lâminas de irrigação por gotejamento na cultura da melancia (Citrullus Lanatus). Bioscience Journal, 20, 29-32.

Trentin, R., Schreiber, F., Streck, N. A., \& Buriol, G. A. (2008). Soma térmica de subperíodos do desenvolvimento da planta de melancia. Ciência Rural, 38, 2464-2470. https://doi.org/10.1590/S0103-84782008000900008

\section{Copyright Disclaimer}

Copyright for this article is retained by the author(s), with first publication rights granted to the journal.

This is an open-access article distributed under the terms and conditions of the Creative Commons Attribution license (http://creativecommons.org/licenses/by/4.0/). 